\title{
Resistance of Different Surfactant Preparations to Inactivation by Meconium
}

\author{
EGBERT HERTING, PETRA RAUPRICH, GUIDO STICHTENOTH, GABI WALTER, \\ JAN JOHANSSON, AND BENGT ROBERTSON \\ Department of Pediatrics, University of Göttingen, D-37075 Göttingen, Germany [E.H., P.R., G.S., G.W.], \\ and Department of Medical Biochemistry and Biophysics [J.J.] and Division for Experimental Perinatal \\ Pathology at the Department of Woman and Child Health [B.R.], Karolinska Institute,
}

S-17176 Stockholm, Sweden

\begin{abstract}
ABST
A disease similar to acute respiratory distress syndrome may
occur in neonates after aspiration of meconium. The aim of the
study was to compare the inhibitory effects of human meconium
on the following surfactant preparations suspended at a concen-
tration of $2.5 \mathrm{mg} / \mathrm{mL}$ : Curosurf, Alveofact, Survanta, Exosurf,
Pumactant, rabbit natural surfactant from bronchoalveolar la-
vage, and two synthetic surfactants based on recombinant sur-
factant protein-C (Venticute) or a leucine/lysine polypeptide.
Minimum surface tension, determined with a pulsating bubble
surfactometer, was increased $>10 \mathrm{mN} / \mathrm{m}$ at meconium concen-
trations $\geq 0.04 \mathrm{mg} / \mathrm{mL}$ for Curosurf, Alveofact, or Survanta,
$\geq 0.32 \mathrm{mg} / \mathrm{mL}$ for recombinant surfactant protein-C, $\geq 1.25$
mg/mL for leucine/lysine polypeptide, and $\geq 20$ mg/mL for
rabbit natural surfactant. The protein-free synthetic surfactants
Exosurf and Pumactant did not reach minimum surface tension
$<10 \mathrm{mN} / \mathrm{m}$ even in the absence of meconium. We conclude that
surfactant activity is inhibited by meconium in a dose-dependent
manner. Recombinant surfactant protein-C and leucine/lysine
polypeptide surfactant were more resistant to inhibition than the
\end{abstract}
Surfactant deficiency has been recognized as the cause of RDS in premature infants, and treatment with modified natural surfactant preparations has considerably improved the prognosis of this disease (1). However, it has been realized that secondary surfactant deficiency caused by inactivation of the surfactant system may occur in patients with mature lungs. In ARDS (acute (adult) RDS), surfactant inhibitors may reach the alveolar space by inhalation or aspiration, and proteins such as albumin or fibrinogen may leak into the airways as a consequence of increased vascular permeability caused by pneumonia, for example (2-4). To treat ARDS in such a patient,

Received July 28, 2000; accepted February 6, 2001.

Correspondence and reprint requests: Egbert Herting, M.D., Ph.D., Department of Pediatrics, University of Göttingen, Robert-Koch Str. 40, D-37075 Göttingen, Germany; e-mail: eherting@med.uni-goettingen.de

Supported by the German Research Council (DFG He 2072/2-2) and a collaborative project (313/S-PPP) of the German Academic Exchange Service (DAAD), the Swedish Research Council (project MFR 3351), and the Swedish Institute (SI). modified natural surfactants Curosurf, Alveofact, or Survanta but less resistant than natural lavage surfactant containing surfactant protein-A. We speculate that recombinant hydrophobic surfactant proteins or synthetic analogs of these proteins can be used for the design of new surfactant preparations that are relatively resistant to inactivation and therefore suitable for treatment of acute respiratory distress syndrome. (Pediatr Res 50: 44-49, 2001)

\begin{tabular}{l}
\multicolumn{1}{c}{ Abbreviations } \\
(A)RDS, (acute) respiratory distress syndrome \\
MAS, meconium aspiration syndrome \\
SP, surfactant protein \\
rSP-C, recombinant surfactant protein C \\
$\mathrm{KL}_{4}$ SP-B-like peptide \\
FFA, free fatty acids \\
DPPC, dipalmitoylphosphatidylcholine \\
PG, phosphatidylglycerol
\end{tabular}

relatively large doses of surfactant need to be instilled to overcome the amount of surfactant inhibitors present in the airways (5). Thus, surfactant preparations used for treatment of ARDS should be relatively resistant to inactivation (6). Recent advances in the synthesis and heterologous expression of lung SPs or their analogs might allow the production of designer surfactants (7) that are highly resistant to surfactant inhibitors. Under ARDS-like conditions, such preparations may be superior to currently available modified natural surfactants.

Aspiration of meconium can result in severe respiratory failure in term neonates $(8-10)$. Surfactant inactivation is believed to play a key role in the pathophysiology of MAS, and inhibition of the surface tension-lowering activity of surfactant by meconium has been demonstrated in vitro $(11,12)$. In addition, in utero events, such as hypoxia, that trigger meconium passage into the amniotic fluid may interfere with surfactant synthesis and secretion by alveolar type II cells (9). In MAS, an early phase of airway obstruction and surfactant 
dysfunction is observed, which is followed by a second phase with a marked inflammatory response in the airways (13). The liberation of cytokines, oxygen radicals, and enzymes (e.g. neutrophil elastase) from phagocytic cells may enhance surfactant inactivation. Apart from its biophysical effects at the air-liquid interface, surfactant has important immunomodulatory functions (14). The surfactant film is also important for fluid homeostasis and mucociliary clearance of aspirated particles. Both these mechanisms may be disturbed in MAS.

Animal models $(15,16)$ and early clinical studies (17-21) demonstrate that lung function and oxygenation in MAS can be improved by instillation of large doses of modified natural surfactants containing phospholipids and SP-B and SP-C.

The aim of the present study was to compare the relative resistance of different surfactant preparations to inactivation by meconium. Three modified natural surfactants (Curosurf, Alveofact, and Survanta) in clinical use in Europe and the United States, two synthetic protein-free surfactants (Exosurf and Pumactant), and two recently described surfactants based on rSP-C or $\mathrm{KL}_{4}$ surfactant were incubated with increasing concentrations of meconium. Minimum surface tension was determined with a pulsating bubble surfactometer (22). Complete natural surfactant containing both the hydrophobic proteins SP-B and SP-C and the hydrophilic proteins SP-A and SP-D was used for comparative studies.

\section{METHODS}

\section{Meconium}

The first meconium of healthy term newborn infants was collected with parental consent. The project was approved by the institutional review board of the Medical University of Göttingen.

Samples from 16 infants were pooled [entry criteria: gestational age, 37-41 wk; birth weight, between 3rd and 97th percentiles; no signs of maternal infection; clear amniotic fluid; no signs of asphyxia (umbilical cord $\mathrm{pH}>7.25$ ); no bacterial contamination of meconium $\left(<10^{4}\right.$ bacteria/mL $\left.)\right]$. The water content of the original meconium pool was $72 \%$. The material was lyophilized and stored at $-70^{\circ} \mathrm{C}$ until use. The dry meconium was resuspended under sonication in saline $0.9 \%$ with 1.5 $\mathrm{mM} \mathrm{CaCl}_{2}$ (23) to reach meconium concentrations from 0.04 to $40 \mathrm{mg} / \mathrm{mL}$. As equal parts of surfactant preparations and meconium suspensions were mixed, the final meconium concentration varied from 0.02 to $20 \mathrm{mg} / \mathrm{mL}$. As up to $200 \mathrm{~g}$ of meconium may be passed by a full-term neonate at birth (9) and the volume of amniotic fluid at birth rarely exceeds 2000 $\mathrm{mL}$, meconium concentrations $>20 \mathrm{mg} / \mathrm{mL}$ can certainly be reached even assuming uniform distribution.

\section{Surfactant}

Natural surfactant. Natural surfactant was obtained by bronchoalveolar lavage of adult rabbit lungs. The surfaceactive material was harvested by sucrose gradient centrifugation (12). As it is not exposed to treatment with organic solvents, complete natural lavage surfactant contains up to $10 \%$ of proteins, including SP-A, SP-B, SP-C, and SP-D.
SP-A represents approximately 50\% (by weight) of the total protein (24).

Modified natural surfactant preparations. Curosurf (batch no. 96/0052, Chiesi Farmaceutici, Parma, Italy) is produced from minced pig lungs and consists of $99 \%$ phospholipids and $1 \%$ hydrophobic surfactant proteins (SP-B and SP-C). Alveofact (SF-RI 1, July 1997, Dr. Karl Thomae Ltd, Biberach, Germany), a compound obtained from bovine lung lavage, is composed of $90 \%$ phospholipids, approximately $1 \%$ hydrophobic proteins, $3 \%$ cholesterol, $0.5 \%$ FFA, and other components such as triglycerides. Survanta (batch no. 95-896Z7, Abbott Ltd, Wiesbaden, Germany) is prepared by lipid extraction of minced bovine lungs and contains approximately $84 \%$ phospholipids, $1 \%$ hydrophobic proteins, and 6\% FFA. To this preparation DPPC mixed with palmitic acid and tripalmitin are added to standardize the composition.

Protein-free synthetic surfactant preparations. Exosurf (batch no. T4798A, Wellcome, Burgwedel, Germany), a synthetic, protein-free surfactant, is composed of approximately 85\% DPPC mixed with cetyl alcohol and tyloxapol. Pumactant [ALEC (artificial lung-expanding compound), batch no. 82, Britannia Pharmaceuticals, Redhill, Surrey, U.K.] is an artificial, protein-free compound composed of a mixture of DPPC and $P G$ at a weight ratio of $7: 3$.

\section{Synthetic surfactant preparations containing peptides/recombinant proteins}

$\mathrm{KL}_{4}$, a 21-residue leucine/lysine peptide (Sinapultide), was synthesized by one of us (J.J.) and combined with DPPC and PG at a weight ratio of $3: 1$ and palmitic acid (15\%) in an isotonic aqueous suspension. The $\mathrm{KL}_{4}$ peptide, added to the lipids at a concentration of $3 \%$, mimics the alternating hydrophobic and hydrophilic pattern of SP-B $(25,26) . \mathrm{KL}_{4}$ has been tested in vitro, in animal experiments, and in clinical trials for treatment of RDS, MAS, and ARDS $(27,28)$. Larger trials with a commercial product (Surfaxin, Discovery Laboratories, Doylestown, PA, U.S.A.) are under way.

rSP-C surfactant (kind gift from D. Häfner, Byk Gulden, Konstanz, Germany) is prepared as an amorphous dry powder and is resuspended in $0.9 \% \mathrm{NaCl}$. The final suspension contains (by weight) 1.8\% rSP-C, 63\% DPPC, 28\% PG, 4.5\% palmitic acid, and $2.5 \% \mathrm{CaCl}_{2}$. In vitro studies and animal experiments indicate excellent biophysical function (29). A clinical study enrolling ARDS patients in Europe, South Africa, the United States, and Canada (30) has recently been started with a commercial product (Venticute, Byln Gulden, Kinslum, Germany). Figure 1 demonstrates the relative differences in composition of the commercially available modified natural surfactant preparations (Alveofact, Curosurf, and Survanta) in comparison with $\mathrm{KL}_{4}, \mathrm{rSP}-\mathrm{C}$, and natural rabbit surfactant $(31,32)$.

\section{Surface tension measurements}

The influence of meconium on the surface activity of the different surfactant preparations was tested in a pulsating bubble surfactometer (Electronetics Corporation, Buffalo, NY, U.S.A.). In all samples the concentration of surfactant was 2.5 


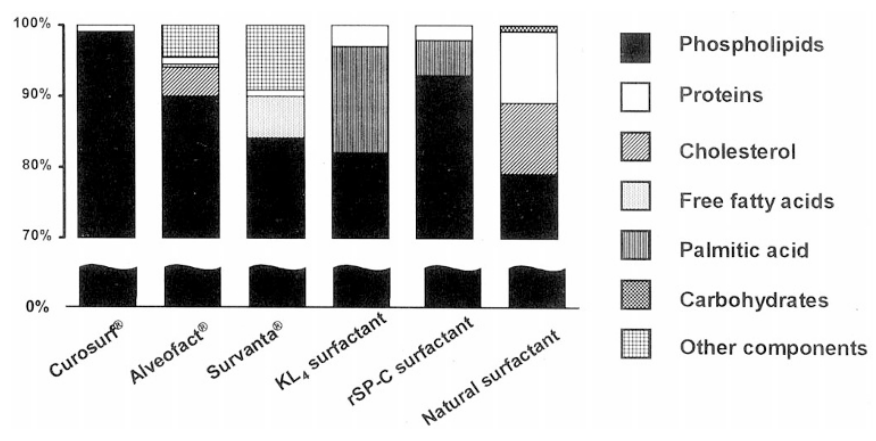

Figure 1. Composition of different surfactant preparations. Modified from Wauer (31) and Seeger et al. (32). All preparations contain $>70 \%$ phospholipids.

$\mathrm{mg} / \mathrm{mL}$, which is close to the estimated critical concentration of surfactant in fetal lung liquid at birth (33). Measurements were made at $37^{\circ} \mathrm{C}$ during $50 \%$ cyclic area compression at a rate of 20 per minute. Surface tension at minimum bubble size $\left(\gamma_{\min }\right)$ was recorded after 5 min of pulsation. Meconium at concentrations ranging from 0.02 to $20 \mathrm{mg} / \mathrm{mL}$ was incubated with the surfactant at $37^{\circ} \mathrm{C}$ for 30 min under gentle agitation before analysis.

$\mathrm{pH}$ values have been shown to influence minimum surface tension of surfactant (34). $\mathrm{pH}$ values of the meconium and surfactant samples at $2.5 \mathrm{mg} / \mathrm{mL}$ ranged from $6.0\left(\mathrm{KL}_{4}\right)$ to 6.7 (rSP-C), with intermediate values for all other surfactants. According to Amirkhanian and Merritt (34), the " $\mathrm{pH}-\mathrm{range}$ $5.0-7.4$ is considered the optimal range for minimum surface tension of surfactants used for in vitro surface tension measurements when evaluating inhibitors of surfactant function."

\section{Statistical analysis}

All data represent the mean $\pm \mathrm{SD}$ of six repeated experiments. Statistical differences were evaluated by ANOVA and Dunnett's multiple comparison test using GraphPad software (Graph Pad Software Inc., San Diego, CA, U.S.A.). Statistical significance was accepted at $p<0.05$.

\section{RESULTS}

Meconium had a dose-dependent inhibitory effect on all examined surfactant preparations. Minimum surface tension was increased $>10 \mathrm{mN} / \mathrm{m}$ at meconium concentrations $>0.04$ $\mathrm{mg} / \mathrm{mL}$ for Curosurf, Alveofact, and Survanta. Survanta seemed to be slightly more resistant to inhibition than Curosurf or Alveofact, but these differences did not reach statistical significance (Fig. 2).

$\mathrm{KL}_{4}$ and rSP-C surfactant were more resistant to the inhibitory effects of meconium. An increase of $\gamma_{\min }>10 \mathrm{mN} / \mathrm{m}$ was observed for rSP-C surfactant at concentrations $>0.16 \mathrm{mg} / \mathrm{mL}$ and for $\mathrm{KL}_{4}$ at meconium concentrations $>0.64 \mathrm{mg} / \mathrm{mL}$ (Fig. 3).

Rabbit natural surfactant prepared by lavage and sucrose gradient centrifugation, containing all SPs including approximately $5 \%$ of SP-A, was far more resistant to inhibition than all other surfactant preparations tested. Addition of $20 \mathrm{mg} / \mathrm{mL}$ meconium was necessary to induce a significant increase in

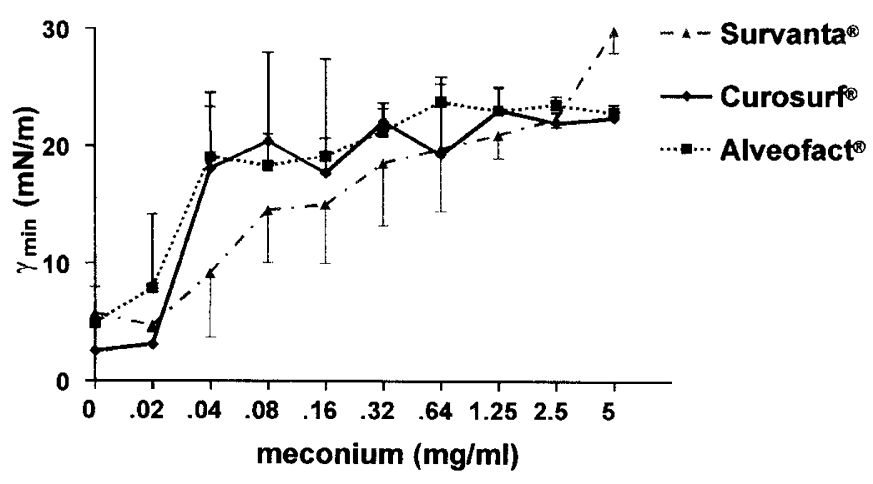

Figure 2. Minimum surface tension $\left(\gamma_{\min }\right)$ of three modified natural surfactant preparations (phospholipid concentration, $2.5 \mathrm{mg} / \mathrm{mL}$ ) exposed to increasing concentrations of human meconium. Values are mean $\pm \mathrm{SD}$ from six repeated experiments. A significant increase in $\gamma_{\min }(p<0.01 v s$ surfactant without meconium, i.e. $0 \mathrm{mg} / \mathrm{mL}$ ) occurred at meconium concentrations $\geq 0.02$ $\mathrm{mg} / \mathrm{mL}$ for Alveofact and at $\geq 0.04 \mathrm{mg} / \mathrm{mL}$ for Curosurf and Survanta.

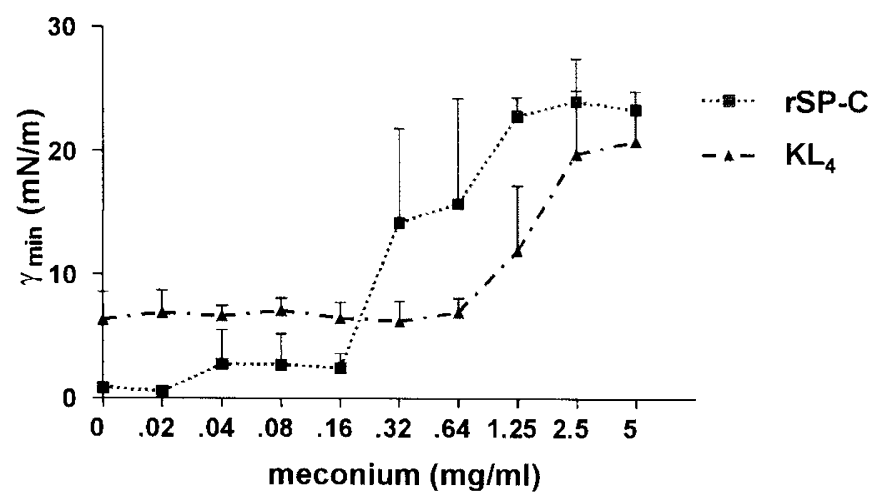

Figure 3. Minimum surface tension $\left(\gamma_{\min }\right)$ of $\mathrm{KL}_{4}$ and rSP-C surfactant (phospholipid concentration, $2.5 \mathrm{mg} / \mathrm{mL}$ ) exposed to increasing concentrations of human meconium. Values are mean $\pm \mathrm{SD}$ from six repeated experiments. A significant increase in $\gamma_{\min }(p<0.01$ vs surfactant without meconium, i.e. 0 $\mathrm{mg} / \mathrm{mL}$ ) occurred at meconium concentrations $\geq 0.32 \mathrm{mg} / \mathrm{mL}$ for $\mathrm{rSP}-\mathrm{C}$ surfactant and at $\geq 1.25 \mathrm{mg} / \mathrm{mL}$ for $\mathrm{KL}_{4}$ surfactant.

minimum surface tension. Figure 4 illustrates the differences in the capacity to resist inactivation by increasing meconium concentrations for modified natural surfactant (Curosurf) containing the hydrophobic surfactant proteins SP-B and SP-C, the two synthetic preparations containing $\mathrm{KL}_{4}$ or $\mathrm{rSP}-\mathrm{C}$, and a complete natural surfactant, containing all surfactant proteins including the hydrophilic SP-A and SP-D.

The inhibition observed by meconium was reversible. For these studies we incubated surfactant $(2.5 \mathrm{mg} / \mathrm{mL})$ with meconium at a concentration of $2.5 \mathrm{mg} / \mathrm{mL}$, a ratio that increased minimum surface tension to $\geq 20 \mathrm{mN} / \mathrm{m}$ for all protein- and peptide-containing surfactants (Fig. 4). When an identical volume of surfactant at a concentration of $7.5 \mathrm{mg} / \mathrm{mL}$ (i.e. final total surfactant concentration, $5 \mathrm{mg} / \mathrm{mL}$ ) was added to the inhibited samples, mean minimum surface tension was reduced again to $2.8 \pm 3.1 \mathrm{mN} / \mathrm{m}$ for Curosurf, $4.6 \pm 5.3 \mathrm{mN} / \mathrm{m}$ for Alveofact, $12.4 \pm 2.3 \mathrm{mN} / \mathrm{m}$ for Survanta, $10.5 \pm 5.0 \mathrm{mN} / \mathrm{m}$ for $\mathrm{KL}_{4}$, and $1.6 \pm 1.0 \mathrm{mN} / \mathrm{m}$ for rSP-C surfactant.

The protein-free synthetic surfactants Exosurf and Pumactant did not reach $\gamma_{\min }<10 \mathrm{mN} / \mathrm{m}$ even in the absence of meconium, so that further studies with increasing meconium concentrations were not performed. 


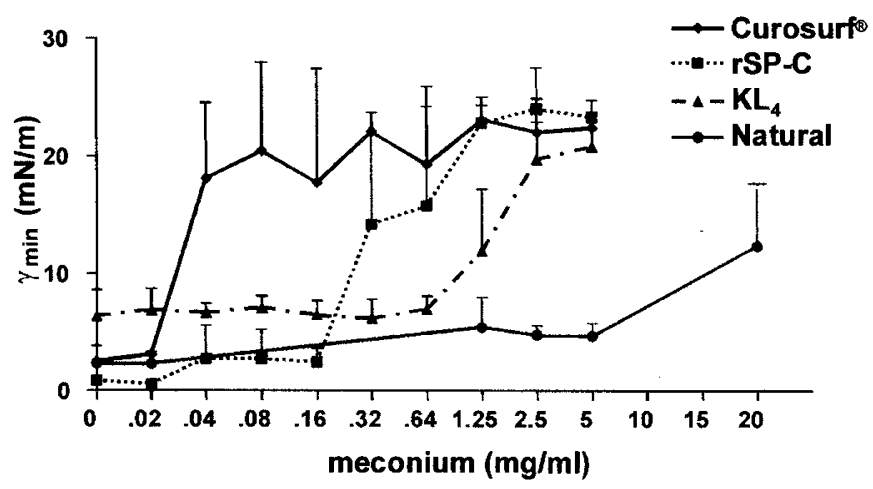

Figure 4. Minimum surface tension $\left(\gamma_{\min }\right)$ of different surfactant preparations (phospholipid concentration, $2.5 \mathrm{mg} / \mathrm{mL}$ ) exposed to increasing concentrations of human meconium. Curosurf, a modified porcine surfactant, and the new synthetic preparations, $\mathrm{KL}_{4}$ and $\mathrm{rSP}-\mathrm{C}$ surfactant, were less resistant to inactivation than complete natural rabbit surfactant obtained by bronchoalveolar lavage. Values are mean $\pm \mathrm{SD}$ from six repeated experiments. An increase in $\gamma_{\min }>10 \mathrm{mN} / \mathrm{m}$ was noted for Curosurf at meconium concentrations $\geq 0.04$ $\mathrm{mg} / \mathrm{mL}$, for $\mathrm{rSP}-\mathrm{C}$ surfactant $\geq 0.32 \mathrm{mg} / \mathrm{mL}$, and for $\mathrm{KL}_{4}$ surfactant at $\geq 1.25$ $\mathrm{mg} / \mathrm{mL}$, whereas $20 \mathrm{mg} / \mathrm{mL}$ of meconium was required to inhibit the natural surfactant.

\section{DISCUSSION}

At a phospholipid concentration of $2.5 \mathrm{mg} / \mathrm{mL}$, all surfactants containing proteins or peptides reduced minimum surface tension to $<10 \mathrm{mN} / \mathrm{m}$ in the absence of meconium. Meconium is a potent inhibitor as an increase in minimum surface tension $>10 \mathrm{mN} / \mathrm{m}$ was observed for all modified natural surfactant preparations already at meconium concentrations between 0.02 and $0.04 \mathrm{mg} / \mathrm{mL}$, i.e. at a ratio of about 1:100 between meconium and surfactant. The concentration of $2.5 \mathrm{mg} / \mathrm{mL}$ makes surfactant more sensitive to inactivation than concentrations $\geq 5 \mathrm{mg} / \mathrm{mL}$ that were used by other investigators (12). The inactivation of surfactant is reversible, as we could demonstrate that addition of extra surfactant to the samples inhibited by meconium restored minimum surface tension to values approximately $\leq 10 \mathrm{mN} / \mathrm{m}$. Thus the differences observed in sensitivity to inactivation in our study may be counteracted to a large extent by modification of the dose of the individual surfactant preparation used. However, it has to be noted that low surface tension in vitro does not necessarily reflect good in vivo activity.

With the protein-free preparations Exosurf and Pumactant, such low values in surface tension were not achieved in the absence of meconium even when the phospholipid concentration was increased to $10 \mathrm{mg} / \mathrm{mL}$. The slow reduction in oxygen demand observed in neonatal RDS after treatment with Exosurf (35) or Pumactant suggests that the exogenous synthetic phospholipids may need to be activated by entering the recycling machinery of the alveolar type II cells to exert a therapeutic effect in the airspaces (36). In clinical trials of RDS and ARDS, Exosurf and Pumactant demonstrated relatively little effects compared with natural modified surfactants $(35,37,38)$.

The exact mechanisms by which meconium interferes with the surfactant layer at the air-liquid interface are as yet unknown. Using electron microscopy, Bae et al. (39) noticed that incubation of Survanta with meconium resulted in a transfor- mation from loosely stacked layers, representing active surfactant, to lamellar or folded linear structures representing inactivated material. These findings are reminiscent of the conversion of the highly surface-active subtype of large surfactant aggregates to small aggregates with poor surface activity observed in adults with ARDS (40). Meconium is a complex mixture containing proteins, cell debris, bile acids, $\mathrm{Hb}$, and bilirubin metabolites, for example (9). All of these components are individually capable of inhibiting surfactant function (4). Both the chloroform-soluble hydrophobic components and the water-soluble components of meconium can interfere with the biophysical activity of surfactant, but the specific inhibitory activity is higher for the chloroform-soluble fraction (12). Probably the incubation of individual components of meconium with surfactant would follow a similar pattern of resistance to inhibition.

Our in vitro results are in keeping with the concept that relatively high surfactant doses are needed for treatment of secondary surfactant deficiency in MAS. Possibly, the presence of a large amount of inhibitors in the alveolar space needs to be overcome by the exogenous surfactant before an effect on lung function and oxygenation can be observed. In a controlled randomized trial using Survanta for early treatment $(<6 \mathrm{~h})$ of MAS, no acute effects on oxygenation were observed after a dose of $150 \mathrm{mg} / \mathrm{kg}$ body weight. When a second dose of 150 $\mathrm{mg} / \mathrm{kg}$ body weight was instilled $6 \mathrm{~h}$ later, there was a significant drop in oxygen demand, and further improvement was seen after administration of a third dose (21). In adults with ARDS caused by sepsis or pneumonia, a dose of $300 \mathrm{mg} / \mathrm{kg}$ body weight of Alveofact was reported to improve gas exchange (5).

For treatment of ARDS, it might be useful to remove surfactant inhibitors from the bronchoalveolar space by lavage with diluted surfactant suspensions. A pilot study has reported the successful use of this approach in neonates with MAS (41). In adults with ARDS, segmental lavage or surfactant instillation by means of a bronchoscope seems feasible (42). Preferably such techniques should be used early in the course of the disease before severe ventilator-induced lung injury has occurred $(43,44)$.

Our present findings together with data reported by others (45) indicate that peptide-containing synthetic surfactant preparations are more resistant to inhibitors than the modified natural surfactants currently used in clinical practice. Recent trials of rSP-C surfactant for treatment of ARDS in adult patients show that improvement in gas exchange can be achieved with doses ranging from 100 to $200 \mathrm{mg} / \mathrm{kg}$ body weight (30), which is in keeping with our in vitro results with $\mathrm{KL}_{4}$ and rSP-C surfactant. However, larger trials are needed to find out whether the improvement in gas exchange is associated with a decrease in mortality. SPs are important factors increasing the resistance of surfactant preparations to inactivation. SP-B and SP-C play a key role for adequate surfactant function especially for rapid spreading and adsorption of the surfactant film (24). Our understanding has been recently enlarged by studies on humans and animals deficient in SPs (46-49). At the moment it seems that either SP-B or SP-C should be present in surfactant preparations to obtain in vivo 
efficacy. Interestingly, Mbagwu et al. (50) observed that the combination of Survanta and two synthetic peptides (B1-78 and $\mathrm{C} 1-35$ ) led to a higher degree of resistance to surfactant inactivation by human albumin in ventilated preterm rabbits. Mizuno et al. (51) reported improved in vivo function of Survanta after SP-B supplementation. Consequently, protein content and composition of surfactant preparations may be critical issues in the design of an artificial surfactant for treatment of $\operatorname{ARDS}(6,7)$.

Although $\mathrm{KL}_{4}$ and $\mathrm{rSP}-\mathrm{C}$ were less sensitive to surfactant inhibition than all other commercially available surfactant preparations, natural surfactant containing all SPs including SP-A and SP-D was even more resistant to loss of biophysical activity by exposure to increasing meconium concentrations. The role of SP-A in the resistance to surfactant inhibitors has been demonstrated in previous studies (52). Sun et al. (53) reported that in a rat model of MAS, natural porcine surfactant containing 5\% SP-A was more effective than the same dose of Curosurf, which contains only polar lipids, SP-B, and SP-C. Addition of SP-A to Curosurf resulted in improved biophysical properties in vitro and better physiologic effects in a rabbit RDS model (53). Recently, the possibility that the carbohydrate components of SP-A might be important for resistance to inactivation led Taeusch et al. (54) to explore the effects of simple sugars, sugar polymers, and other nonionic polymers on surfactant inactivation by meconium. Interestingly, dextran and polyethylene glycol reversed the inactivation of Survanta by meconium. Similar data were recently reported by Tashiro et al. (55) for Curosurf fortified with dextran. Consequently, it might be possible to enhance the resistance of surfactant preparations by adding other components than naturally occurring or recombinant SPs. Differences in lipid composition, illustrated in Figure 1, also need to be considered in this context. For example, significant amounts of palmitic acid are added to Survanta and $\mathrm{KL}_{4}$ surfactant. Further systematic studies are required to clarify how variations in the content of palmitic acid and other lipid constituents influence resistance to inactivation by meconium and plasma proteins. In the present study differences among modified natural surfactants used for treatment of neonatal RDS today were moderate and might only indicate the need for different dosage regimens for preparations of different origin.

We conclude that meconium is a potent inhibitor of all investigated surfactant preparations. The artificial rSP-C and $\mathrm{KL}_{4}$ surfactants were more resistant to inhibition than the modified natural surfactants Curosurf, Alveofact, or Survanta, which are currently in clinical use. However, natural surfactant containing SP-A was still more resistant to inactivation. Recombinant proteins or synthetic analogs of these proteins can probably be used for making surfactants that are relatively resistant to inactivation and therefore suitable for treatment of ARDS and related conditions, including MAS.

\section{REFERENCES}

1. Jobe AH 1993 Pulmonary surfactant therapy. N Engl J Med 328:861-868

2. Fuchimukai T, Fujiwara T, Takahashi A, Enhorning G 1987 Artificial pulmonary surfactant inhibited by proteins. J Appl Physiol 62:429-437
3. Seeger W, Stöhr G, Wolf HRD, Heuhof H1985 Alteration of surfactant function due to protein leakage: special interaction with fibrin monomer. J Appl Physiol 58:326338

4. Holm BA 1993 Surfactant inactivation in the adult respiratory distress syndrome. In: Robertson B, van Golde LMG, Batenburg JJ (eds) Pulmonary surfactant: from molecular biology to clinical practice. Elsevier, Amsterdam, pp 665-684

5. Walmrath D, Günther A, Ghofrani HA, Schermuly R, Schneider T, Grimminger F, Seeger W 1996 Bronchoscopic surfactant administration in patients with severe adult respiratory distress syndrome and sepsis. Am J Respir Crit Care Med 154:57-62

6. Robertson B 1998 Surfactant inactivation and surfactant therapy in acute respiratory distress syndrome (ARDS). Monaldi Arch Chest Dis 53:64-69

7. Holm BA, Waring AJ 1993 Designer surfactants: the next generation in surfactant replacement. Clin Perinatol 20:813-829

8. Wiswell TE, Tuggle JM, Turner BS 1990 Meconium aspiration syndrome: have we made a difference? Pediatrics 85:715-721

9. Cleary GM, Wiswell TE 1998 Meconium-stained amniotic fluid and the meconium aspiration syndrome. Pediatr Clin North Am 45:511-529

10. Wiswell TE, Gannon CM, Jacob J, Goldsmith L, Szyld E, Weiss K, Schutzmann D, Cleary GM, Filipov P, Kurlat I, Caballero CL, Abassi S, Sprague D, Oltorf C, Padula M 2000 Delivery room management of the apparently vigorous meconium-stained neonate: results of the multicenter, international collaborative trial. Pediatrics 105:1-7

11. Moses D, Holm BA, Spitale P, Liu MY, Enhorning G 1991 Inhibition of pulmonary surfactant function by meconium. Am J Obstet Gynecol 164:477-481

12. Sun B, Curstedt T, Robertson B 1993 Surfactant inhibition in experimental meconium aspiration. Acta Paediatr 82:182-189

13. Davey AM, Becker JD, Davis JM 1993 Meconium aspiration syndrome: physiological and inflammatory changes in a newborn piglet model. Pediatr Pulmonol 16:101108

14. Wright JR 1997 Immunomodulatory functions of surfactant. Physiol Rev 77:931-962

15. Sun B, Herting E, Curstedt, T, Robertson B 1994 Exogenous surfactant improves lung compliance and oxygenation in adult rats with meconium aspiration. J Appl Physiol 77:1961-1971

16. Paranka MS, Walsh WF, Stancombe BB 1992 Surfactant lavage in a piglet model of meconium aspiration syndrome. Pediatr Res 31:625-628

17. Auten RL, Notter RH, Kendig JW, Davis JM, Shapiro DL 1991 Surfactant treatment of full-term newborns with respiratory failure. Pediatrics 87:101-107

18. Khammash H, Perlman M, Wojtulewicz J, Dunn M 1993 Surfactant therapy in full-term neonates with severe respiratory failure. Pediatrics 92:135-139

19. Halliday HL, Speer CP, Robertson B 1996 Treatment of severe meconium aspiration syndrome with porcine surfactant. Eur J Pediatr 155:1047-1051

20. Lotze A, Mitchell BR, Bulas DI, Zola EM, Shalwitz RA, Gunkel JH 1998 Multicenter study of surfactant (Beractant) use in the treatment of term infants with severe respiratory failure: Survanta in Term Infants Study Group. J Pediatr 132:40-47

21. Findlay RD, Taeusch HW, Walther FJ 1996 Surfactant replacement therapy for meconium aspiration syndrome. Pediatrics 97:48-52

22. Enhorning G, Shumel B, Keicher L, Sokolowski J, Holm BA 1992 Phospholipases introduced into the hypophase affect the surfactant film outlining a bubble. J Appl Physiol 73:941-945

23. Kobayashi T, Robertson B 1983 Surface adsorption of pulmonary surfactant in relation to bulk phase concentration and presence of $\mathrm{CaCl}_{2}$. Respiration 44:63-70

24. Johansson J, Curstedt T, Robertson B 1994 The proteins of the surfactant system. Eur Respir J 7:372-391

25. Revak S, Merritt TA, Hallman M, Cochrane C 1986 Reconstitution of surfactant activity using purified human apoprotein and phospholipids measured in vitro and in vivo. Am Rev Respir Dis 134:1258-1265

26. Nilsson G, Gustafsson M, Vandenbussche G, Veldhuizen E, Griffiths WJ, Sjövall J, Haagsman HP, Ruysschaert JM, Robertson B, Curstedt T, Johansson J 1998 Synthetic peptide-containing surfactants: evaluation of transmembrane versus amphipathic helices and SP-C poly-valyl to poly-leucyl substitution. Eur J Biochem 255:116-124

27. Cochrane CG, Revak SD, Merritt TA, Heldt GP, Hallman M, Cunningham MD, Easa D, Pramanik A, Edwards DK, Alberts MS 1996 The efficacy and safety of $\mathrm{KL}_{4}$ surfactant in preterm infants with respiratory distress syndrome. Am J Respir Crit Care Med 153:404-410

28. Cochrane CG, Revak SD, Merritt A, Schraufstätter IU, Hoch RC, Henderson CH, Andersson S, Takamori H, Oades ZG 1998 Bronchoalveolar lavage with $\mathrm{KL}_{4}$ surfactant in models of meconium aspiration syndrome. Pediatr Res 44:705-715

29. Häfner D, Germann PG, Hauschke D 1998 Effects of rSP-C surfactant on oxygenation and histology in a rat-lung-lavage model of acute lung injury. Am J Respir Crit Care Med 158:270-278

30. Spragg RG, Lewis J, Wurst W, Rathgeb F 2000 Treatment of ARDS with rSP-C surfactant. Am J Respir Crit Care Med 161:A47(abstr)

31. Wauer R 1998 Respiratory distress syndrome. In: Wauer RR (ed) Surfactant therapy: basic principles, diagnosis, therapy. Thieme, Stuttgart, pp 2-19

32. Seeger W, Grube C, Günther A, Schmidt R 1993 Surfactant inhibition by plasma proteins: differential sensitivity of various surfactant preparations. Eur Respir J 6:971-977

33. Kobayashi T, Shido A, Nitta K, Inui S, Ganzuka M, Robertson B 1990 The critical concentration of surfactant in fetal lung liquid at birth. Respir Physiol 80:181-192

34. Amirkhanian JD, Merritt TA 1995 The influence of $\mathrm{pH}$ on surface properties of lung surfactants. Lung 173:243-254

35. Halliday HL 1995 Overview of clinical trials comparing natural and synthetic surfactants. Biol Neonate 67:32-47

36. Jobe AH, Ikegami M 1993 Surfactant metabolism. Clin Perinatol 20:683-696

37. Anzueto A, Baughman RP, Guntupalli KK, Weg JG, Wiedemann HP, Raventos AA, Lemaire F, Long W, Zaccardelli DS, Pattishall EN 1996 Aerosolized 
surfactant in adults with sepsis-induced acute respiratory distress syndrome: Exosurf Acute Respiratory Distress Syndrome Sepsis Study Group. N Engl J Med 334:1417-1421

38. Ainsworth SB, Beresford MW, Milligan DWA, Shaw NJ, Matthews JN, Fenton AC, Ward Platt MP 2000 Pumactant and Poractant alfa for treatment of respiratory distress syndrome in neonates born at 25-29 weeks' gestation: a randomised trial. Lancet 355:1387-1392

39. Bae CW, Takahashi A, Chida, S, Sasaki M 1998 Morphology and function of pulmonary surfactant inhibited by meconium. Pediatr Res 44:187-191

40. Günther A, Schmidt R, Feustel A, Meier U, Pucker C, Ermert M, Seeger W 1999 Surfactant subtype conversion is related to loss of surfactant apoprotein B and surface activity in large surfactant aggregates: experimental and clinical studies. Am J Respir Crit Care Med 159:244-251

41. Lam BC, Yeung CY 1999 Surfactant lavage for meconium aspiration syndrome: a pilot study. Pediatrics 103:1014-1018

42. Wiswell TE, Smith RM, Katz LB, Mastroianni L, Wong DY, Willms D, Heard S, Wilson M, Hite RD, Anzueto A, Revak SD, Cochrane CG 1999 Bronchopulmonary segmental lavage with Surfaxin $\left(\mathrm{KL}_{4}\right.$-surfactant) for acute respiratory distress syndrome (ARDS). Am J Respir Crit Care Med 160:1188-1195

43. Brower RG, Matthay MA, Morris A, Schoenfeld D, Thompson BT 2000 Ventilation with lower tidal volumes as compared with traditional tidal volumes for acute lung injury and the acute respiratory distress syndrome. N Engl J Med 342:1301-1308

44. Ware LB, Matthay MA 2000 The acute respiratory distress syndrome. N Engl J Med 342:1334-1349

45. Manalo E, Merritt TA, Kheiter A, Amirkhanian J, Cochrane C 1996 Comparative effects of some serum components and proteolytic products of fibrinogen on surface tension-lowering abilities of Beractant and a synthetic peptide containing surfactant KL4. Pediatr Res 39:947-952
46. Nogee L, Garnier G, Singer L, Dietz H, Murphy A, Cutting G 1994 A mutation in the surfactant protein $\mathrm{B}$ gene responsible for fatal neonatal respiratory disease in multiple kindreds. J Clin Invest 93:1860-1863

47. Robertson B, Johansson J, Curstedt T 2000 Synthetic surfactants to treat neonatal lung disease. Mol Med Today 6:119-124

48. Weaver TE 1988 Synthesis, processing and secretion of surfactant proteins B and C. Biochim Biophys Acta 1408:173-179

49. Botas C, Poulain F, Akiyama J, Brown C, Allen L, Goerke J, Clements J, Carlson E, Gillespie AM, Epstein CH, Hawgood S 1998 Altered surfactant homeostasis and alveolar type II cell morphology in mice lacking surfactant protein D. Proc Natl Acad Sci USA 95:11869-11874

50. Mbagwu N, Bruni R, Hernández-Huviel JM, Waring JA, Walther FJ 1999 Sensitivity of synthetic surfactants to albumin inhibition in preterm rabbits. Mol Gen Metabol $66: 40-48$

51. Mizuno K, Ikegami M, Chen CM, Ueda T, Jobe AH 1995 Surfactant protein-B supplementation improves in vivo function of a modified natural surfactant. Pediatr Res 37:271-276

52. Cockshutt AM, Weitz J, Possmayer F 1990 Pulmonary surfactant-associated protein A enhances the surface activity of lipid extract surfactant and reverses inhibition by blood proteins in vitro. Biochemistry 29:8424-8429

53. Sun B, Curstedt T, Lindgren G, Franzén B, Alaiya AA, Calkovská A, Robertson B 1997 Biophysical and physiological properties of a modified porcine surfactant enriched with surfactant protein A. Eur Respir J 10:1967-1974

54. Taeusch W, Lu KL, Goerke J, Clements J 1999 Nonionic polymers reverse inactivation of surfactant by meconium and other substances. Am J Respir Crit Care Med 159:1391-1395

55. Tashiro K, Kobayashi T, Robertson B 2000 Dextran reduces surfactant inhibition by meconium. Acta Paediatr 89:1439-1445 